\title{
Speaking Marathon: Solusi Meningkatkan Motivasi Berbicara Bahasa Inggris di Pesantren Al-Ghozali
}

\author{
Lida Holida Mahmud', Yamin'², Mursyid Anwar ${ }^{3}$, Tryana ${ }^{4}$ \\ Universitas Pamulang ${ }^{1234}$ \\ Korepondesi: dosen00514@unpam.ac.id',dosen01094@unpam.ac.id², \\ dosen01428@unpam.ac.id ${ }^{3}$,dosen00420@unpam.ac.id ${ }^{4}$
}

\begin{abstract}
Based on observation, Community Service Activities (PKM) in Pondok Pesantren Al-Ghozali Bogor purposes to improve Students' Willingness to Communicate in English. This PKM uses Speaking Marathon method as a short warm up activity. This method involves theory Mclyntire (1998) that relates willingness to communicate to learning motivation and anxiety. The PKM used Simulation through learning video of Speaking Marathon and Mentored method. From the result of this PKM activities, it was found that Speaking Marathon provides an enhancement in willingness to communicate among students towards English Speaking through the rule of Speaking Marathon ignoring grammatical and spelling errors. It also found that this rule has eliminated students' anxiety and emerged motivation to speak up. However, it still needs diligence of students to have better learning for boosting their skill. It can be concluded that Speaking Marathon provided solution for students of Pesantren Al-Ghozali to minimize unwillingness to communicate in English.
\end{abstract}

Keywords: speaking, marathon, willingness, communicate

\begin{abstract}
Abstrak
Berdasarkan observasi, kegiatan Pengambdian Kepada Masyarakat (PKM) di Pondok Pesantren AlGhozali bertujuan untuk meningkattkan kemauan berkomunikasi dengan berbicara bahasa Inggris dikalangan santri. PKM ini menggunakan metode Speaking Marathon dengan melibatkan teori Mclyntire (2007) yang menghubungkan antara kemauan berkomunikasi dengan motivasi dan kekhawatiran dan belajar. PKM ini menggunakan pendekatan simulasi melalui video pembelajaran terkait Speaking Marathon dan pendampingan. Dari hasil PKM ditemukan bahwa Speaking Marathon memberikan respon positif dalam meningkatkan kemauan berbicara siswa melalui aturan dalam metoda tersebut yang mengkesampingkan kesalahan berbahasa baik dari segi grammar, kosakata maupun pelafalan. Aturan tersebut dapat meminimalisir rasa khawatir siswa dalam melakukan kesalahan berbicara sehingga membangkitkan motivasi untuk terus berbicara dalam bahasa Inggris dengan percaya diri dan tanpa rasa takut, sehingga keraguan dan ketidakmauan berkomunikasi dalam bahasa Inggris dapat diminimalisir. Namun demikian, tetap dibutuhkan pendampingan dari guru pendamping dan ketekunan dari para siswa untuk terus berlatih dan mau belajar lebih baik lagi agar keterampilannya terus meningkat.
\end{abstract}

Kata kunci: bicara, marathon, motivasi, berkomunikasi 


\section{A. Pendahuluan}

Sejalan dengan proses globalisai yang semakin intensif yang ditandai dengan derasnya arus informasi dari dalam maupun luar negeri yang mencakup berbagai apek kehidupan, membuat dunia seakan semakin menyempit. Tidak ada batas batas antar negara yang satu dengan yang lain. Kita yang hidup dan beraktifitas di Indonesia, dengan sangat mudah berinterkasi dengan orang lain yang berada dibelahan bumi lainya. Semua orang saat ini bebas berkomunikasi, dan berbisnis dengan orang dari negara atau bahkan benua lain. Hal ini menjadi tantangan tersendiri dalam era globalisasi. Mau tidak mau, kita dituntut untuk menguasai bahasa dunia. Salah satunya adalah bahasa Inggris. Dengan kemampuan berbahasa asing khususnya bahasa Inggris, para siswa dan generasi muda penerus bangsa memiliki kesempatan yang luas untuk mengakses berbagai informasi yang diperlukan untuk melakukan berbagai kegiatan. Kemampuan dan keberanian untuk turut serta dalam berkomunikasi secara global, menyampaikan gagasan dan ide-ide membangun, akan menjadi modal tersendiri dalam rangka berkomunikasi untuk menjalin perbagai urusan.

Namun fakta dilapangan saat ini masih banyak siswa- siswi dari berbagai tingkat pendidikan baik SD, SMP, maupun SMA yang belum mampu berbahasa Inggris dengan baik di dalam maupun di luar sekolah. Menjadikan siswa-siswi mampu berbicara dalam bahasa Inggris bukanlah hal yang mudah jika tidak diimbangi oleh sistem pengajaran yang baik. Masih banyaknya kendala yang dihadapi agar para siswa-siswi bisa berbahasa Inggris dengan baik, seperti masih minimnya sarana dan prasarana pembelajaran, kondisi sosial ekonomi keluarga mereka, serta model pembelajaran oleh para pendidik yang kurang variatif. Oleh karenanya perlu adanya kreatifitas dari para pendidik khusunya bagaimana menyajikan tehnik-tehnik dan metode pembelajaran yang menarik. Termasuk didalamnya mencari cara bagaimana meningkatkan kepercayaan diri siswa dalam berbicara Bahasa Inggris termasuk penguasaan kosakatanya. Sehingga dengan keterampilannya dalam berkomunikasi secara global menjadi bekal siswa dalam melanjutkan ke jenjang selanjutnya ataupun ketika harus terjun langsung sebagai pelaku masyarakat

Keterampilan berkomunikasi secara global ini sejalan dengan visi dari salah satu pesantren yang ada di kabupaten Bogor, Yayasan Pendidikan Islam Al-Ghozali, yaitu terwujudnya pondok pesantren yang unggul, berkualitas dan relevan menuju terbentuknya sumber daya manusia yang islami dan excellent yang memiliki kecerdasan global, baik spiritual, intelektual, emosional, kreatif dan nilai-nilai profesionalisme yang berlandaskan Al-Quran, Hadis serta Pancasila dan UUD 1945. Yayasan Pendidikan Islam Al-Ghozali ini didirikan pada tanggal 11 Januari 1982. Pondok Modern Al-Ghozali beralamat di Jl. Permata No.19 Curug Kecamatan Gunungsindur, Kabupaten Bogor, Jawa Barat. Lembaga ini adalah salah satu pondok pesanteran modern yang berkembang di daerah tersebut. Peserta didik di Ponpes AlGhozali merupakan santriwan-santriwati yang sedang mengenyam pendidikan tingkat sekolah menengah atas. Mayoritas mereka berasal dari Jakarta, Bogor, Tangerang, Banten, bahkan beberapa ada yang berasal dari luar pulau Jawa. Usia mereka pun beraneka ragam; dengan kisaran umur antara 16 sampai dengan 20 tahun. Semua 
peserta mukim atau tinggal di Asrama Pondok Pesantren Al-Ghozali Gunungsindur, Bogor. Setidaknya terdapat lebih dari 1000 santriwan-santriwati yang menimba ilmu di tempat ini.

Untuk mewujudkan visinya, Pesantren AL-Ghozali menuangkan strateginya ke dalam beberapa misi diantaranya mewujudkan integritas kurikulum pendidikan yang berwawasan global dengan tetap mengedepankan syariat Islam serta mewujudkan proses pembelajaran yang berkualitas dan menyenangkan dengan berbasis teknologi. Misi tersebut bertujuan guna memfasilitasi masyarakat sekitar untuk menimba ilmu, yang kemudian diharapkan mampu mengaplikasikan nilai-nilai luhur agama dalam kehidupan sehari-hari. Untuk merealissikan cita-cita tersebut, Pondok Pesantren memberikan pengajaran bahasa Inggris kepada seluruh santrinya khususnya English Speaking. Speaking dianggap puncak akumulasi kemampuan keterampilan suatu bahasa dari keterampilan yang harus dimiliki dalam satu bahasa yaitu reading, writing , grammar dan speaking. Celce and Murcia (2001, p. 103) menyatakan bahwa "Speaking is one of communicative skills that indicates that the learner can master English Language actively because speech is the most basic means of human communication". Sejalan dengan hal ini, Khairiyah (2013, p. 13) mengkonfimasi bagaimana berbicara menjadi puncak kemampuan berbahasa adalah karena berbicara merupakan alat penyampaian maksud yang bisa berupa gagasan, pikiran dan isi hati seseorang kepada orang lain. Tidak heran English Speaking menjadi target wajib dari para santri pondok pesantren Al-Ghozali,

Namun demikian, berdasarkan hasil survey Tim PKM UNPAM, masih ditemukan beberapa permasalahan yang menghambat terwujudnya visi misi pondok pesantren tersebut. Antara lain: kurangnya kesadaran akan pentingnya bahasa Inggris seringkali membuat santri tidak tertarik untuk mempelajarinya sehingga tidak ada usaha atau kemauan untuk berbicara dengan menggunakan bahasa Inggris. Selain itu, banyak dari para siswa yang merasa khawatir dan takut melakukan kesalahan ketika berbicara Bahasa Ingris sehingga pada akhirnya mereka lebih memilih pasif. Masalah lainnya, beberapa anak yang kurang rasa percaya diri saat berbahasa Inggris karena sedikit menguasai kosakata. Minimnya contoh penggunaan bahasa Inggris dalam kehidupan sehari-hari seringkali membuat para santri mengalami kesulitan dalam menghubungkan apa yang mereka pelajari dalam bahasa Inggris dengan kehidupan mereka. Dari beberapa permasalahan yang ditemukan berdasarkan hasil survei dan observasi tersebut, maka realisasi pemecahan masalah yang harus diambil berfokus pada 2 hal yaitu bagaimana meningkatkan motivasi siswa untuk speak up atau berbicara (willingness to communicate) dan bagaimana meningkatan kepercayaan diri siswa tanpa merasa takut melakukan kesalahan berbicara. Terkait dengan tersebut tim PkM UNPAM memilih Speaking Marathon sebagai solusi atas permasalahan yang ada di Pesantren Al-Ghozali tersebut.

\section{B. Pelaksanaan dan Metode}

Dalam masa pandemi covid, sesuai dengan program pemerintah bahwa Pelaksanaan kegiatan PkM tidak bisa dilakukan secara tatap muka, maka solusi yang ditawarkan untuk PkM di Pesantren Al-Ghozali dilakukan dalam bentuk pembuatan 
video Speaking Marathon oleh dosen dan mahasiswa UNPAM prodi Sastra Inggris, yang selanjutnya diaplikasikan di Pesantren Al-Ghozali dengan pendampingan secara online. Kegiatan puncak pembuatan video dilaksanakan pada tanggal 11 s.d 13 Desember 2020. Kegiatan PkM ini dilakukan dengan metode simulasi. Teknik Speaking Marathon sama hklnya dengan tekhnik lari marathon yang artinya terus menerus tanpa berhenti. Speaking Marathon ini mengharuskan peserta didik untuk terus menerus tanpa berhenti berbicara bahasa Inggris selama tenggang waktu yang ditentukan tanpa melihat salah dan benar untuk tata bahasanya. Dalam Speaking Marathon apabila terjadi kesalahan berbicara tidak akan terkena hukuman sehingga santri tidak merasa terbebani dan khawatir yang pada akhirnya diharapkan mendorong pembelajar terus menerus mengucapkan pemikirannya dalam bahasa inggris tanpa beban, canggung, khwatir dan takut berlebih akan terjadi kesalahan dalam berbicara sebagaimana Xie (2011, p. 99) menyebutkan bahwa rasa khawatir dan takut berlebih akan menghilangkan kemauan untuk berkomunikasi atau berbicara (unwillingness to communicate).

Tujuan dari metode Speaking Marathon ini mendorong santri terbiasa berbicara dan terus berbicara Bahasa Inggris tanpa takut dan khawatir melakukan kesalahan berbicara. Ketika sesorang terdorong selalu berbicara tanpa merasa takut atau terbebani diharapkan outputnya yaitu Speaking English bisa menjadi alat komunikasi sehari-hari. Sebagaimana kita ketahui, Speaking English merupakan keterampilan berkomunikasi yang mengindikasi bahwa santri terampil berbahasa Inggris secara aktif karena berbicara merupakan titik akumulasi perpaduan dari keterampilan berbahasa lainnya yaitu reading (membaca), listening (mendengar), writing (menulis dan grammar (tata bahasa). Hal terpenting yang ditekankan dalam metode Speaking Marathon terfokus pada 2 hal yaitu Speak Up/talk and talk atau bicara dan terus bicara serta willingness to communicate atau kemauan untuk berbicaranya itu sendiri tanpa merasa khawatir, gugup ataupun takut. Sedangkan dalam aspek sosial solusi, pada PKM ini menggunakan pendekatan pendampingan oleh guru/pengajar sehingga speaking marathon ini bisa dilaksanaka dengan optimal sehingga hasilnya bisa maksimal. Adapun metoda pelaksanaan Speaking Marathon adalah sebagai berikut: 1). Pembelajar bisa dibagi kedalam 2 kelompok ataupun perorangan. Apabila dibentuk kelompok maka 2 kelompok akan saling berhadapan. 2). Guru/pendamping menjelaskan aturan dan waktu yang ditentukan. Setelah itu melemparkan sebuah tema kepada kedua kelompok tersebut dan mereka harus terus saling berbicara tanpa berhenti. Kelompok pertama bisa memulai dengan "How are you" yang selanjutnya akan dibalas tanpa keluar dari tema. Selama percakapan berlangsung guru mengamati tanpa mengkoreksi mereka. Guru hanya memastikan bahwa siswanya berbicara normal selayakanya percakapan sehari hari. 3). Dalam aturan marathon speaking, guru sebelumnya menjelaskan kepada siswa apabila siswa mengalami blank thinking dilarang untuk untuk mengucapkan I don't know, tetapi diganti dengan "I am not really sure". Dan apabila siswa dalam keadaan berpikir agak lama dilarang untuk mengucapkan eee tetapi diganti dengan kata "Well" atau "you know that..". 4). Apabila salah satu siswa pada suatu kelompok tidak berbicara dalam hitungan 5 detik maka siswa tersebut dipersilahkan untuk duduk kembali. Kelompok yang anggotanya paling banyak berdiri maka itulah pemenangnya. 
Adapun tahap pelaksanaan PkM Speaking Marathon terdiri dari 3 tahap. Tahap ke-1 berupa observasi dan survey terkait permasalahan di Pesantren Al-Ghozali. Tahap ke 2 mengarah pada rangkaian pelaksanaan PkM itu sendiri, dan tahap ke-3 adalah fokus pada penyusunan laporan dan jurnal Pengabdian Masyarakat baik secara soft copy maupun hard copy. Tujuan pelaporan dan jurnal itu sendiri adalah sebagai hasil luaran $\mathrm{PkM}$ disamping sebagai dasar rekomendasi bagi pelaksanaan $\mathrm{PkM}$ selanjutnya. Berikut rangkaian pelaksanaan PkM Speaking Marathon:

Jumat 15 November 2020: Rapat Persiapan I melalui Zoom Meeting antara dosen dan mahasiswa terkait tema dan sarana prasarana pembuatan video Speaking Marathon

Sabtu, 18 November 2020: Rapat Persiapan II melalui Zoom Meeting dihadiri dosen dan mahasiswa terkait Tekhnik Pembuatan Video

Jumat s.d Minggu, 11 s.d 13 Desember 2020 : Pembuatan Video

Minggu Ke 2 Januari : Mulai diaplikasikan di Pesantren Al-Ghozali.

Video yang dibuat berdurasi 18 menit. 3 Menit pertama berupa penjelasan tentang Speaking Marathon dan 15 menit berupa simulasi atau praktek Speaking Marathon.
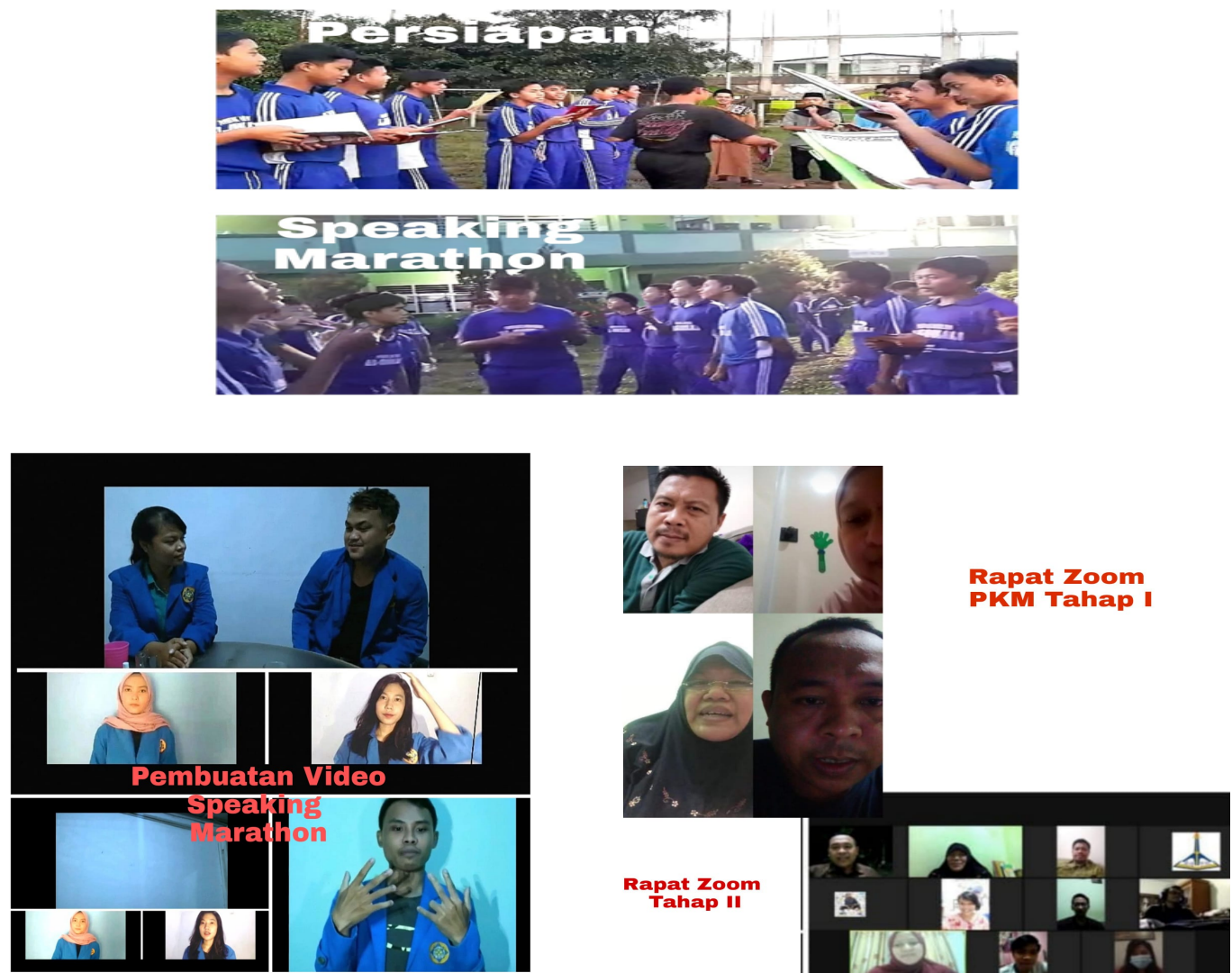

$\overline{\text { ACITYA BHAKTI, Volume } 1 \text { Nomor 2, Agustus } 2021}$ 
Speaking Marathon: Solusi Meningkatkan Motivasi Berbicara Bahasa Inggris

\section{Hasil dan Pembahasan}

Dari data yang diperoleh di Pesantren AL-Ghozali memperlihatkan bahwa metode Speaking Martahon bisa menjadi solusi untuk meningkatkan kemauan siswa dalam berbicara bahasa Inggris dengan melihat indikator sebagai berikut: 1). Dari catatan guru pendamping, ditegaskan kepada siswa/santri bahwa kegiatan tersebut tidak memperhitungkan salah dan benarnya ketatabahasaan. Pada awal kegiatan disepakati tema dan santri boleh melihat dan menghapal catatan beberapa vocabulary terkait tema tersebut. Pada saat giliran berbicara (conversation) santri sudah tidak boleh melihat catatan tersebut. Pada awalnya beberapa santri masih ada yang terputus bicara lebih dari lima detik karena terhenti ide bicara atau lupa kosakata sehingga reflek melihat catatan, konsekwensinya mereka harus keluar dari permainan, tetapi dalam tema berikutnya sampai waktu kesepakatan berakhir jumlah siswa yang yang terputus bicara semakin berkurang. Dalam theory motivasi Gardner dalam Brown (2001, p. 75) menemukan bahwa motivasi secara bertahap memberikan pengaruh yang besar pada kemauan belajar. Pada aktivitas English Speaking biasa sering kita temukan sebagian siswa dengan mudah terlibat dalam aktivitas percakapan, tetapi sebagian lainnya mungkin akan menghindarinya. Akan tetapi, metode dan aturan dalam speaking marathon yang tidak memperhitungkan salah benarnya ketata bahasaan siswa dalam berbicara, memotivasi semua siswa untuk terus dan terus berbicara tanpa beban. Dari hal tersebut, metode dan aturan dalam Speaking Marathon menjadi suatu proses motivasi yang berlangsung secara bertahap mendorong santri untuk berbicara. Hal ini sejalan dengan theory Willingness to communicate (Mclyntye et al, 1998) bahwa motivasi mendorong adanya willingness to communicate (kemauan untuk berkomunikasi) dan sebaliknya ketiadaan motivasi menyebabkan adanya unwillingness to communicate. 2). Adanya antusiasme santri untuk terlibat dalam Speaking Marathon secara tidak langsung menunjukan rasa nyaman dan menyenangkan pada diri santri. Josephs et al in Fulmer (2010, p. 23) menyatakan bahwa "Speak up" atau berbicara merupakan bentuk kemauan dalam berkomunikasi yang prosesnya terjadi ketika kenyamanan terbentuk pada diri si penutur yang disebabkan hasil evaluasi terhadap dirinya sendiri dan terhadap lingkungannya (self esteem). Dalam aktivitas Speaking Marathon, aturan main yang melarang guru pendamping mengkoreksi kesalahan tata Bahasa si pembelajar secara tidak langsung memberikan rasa nyaman pada santri untuk terus berbicara tanpa takut salah meskipun mereka menyadari kekurangan mereka sendiri . 3). Dalam aktivitas Speaking Marathon, guru pendamping memang tidak diperkenankan untuk mengkoreksi kesalahan tata bahasa, akan tetapi selama berjalannya aktivitas, guru pendamping memperhatikan dan mencatat setiap kesulitan berbicara khususnya ketika ada kejadian berhenti bercakap dalam waktu 5 detik yang dihadapi siswanya. Pada akhir aktivitas, guru bisa mendiskusikan dengan siswa terkait kesulitan yang tadi dihadapinya termasuk terkait kosakata atau ekspresi yang tepat. Sehingga pada aktivitas tema berikutnya apabila siswa ada kemungkinanan menggunakan kosakata atau ekspresi tersebut lagi diharapkan tidak terjadi lagi jeda bicara. Dengan hal ini diharapkan kosakata siswa meningkat. 4). Angraini dan Rahhmiati (2017) menemukan bahwa hampir 70\% siswa yang tergabung dalam kelas speaking untuk 
EFL mengalami rasa gugup dan khawatir dengan ditandai symptom fisik berupa gagap, beringat, dan simpton khawatir lainnya. Dalam aktifitas Speaking Marathon, tidak adanya hukuman atau teguran saat melakukan kesalahan dalam berbicara bahasa inggris menyebabkan siswa mau mengungkapakan isi pikiran mereka dengan bicara dan terus bicara, sehingga diharapkan kepercayaan diri meningkat. Pada PkM ini, Meskipun beberapa santri diantaranya masih melakukan beberapa kesalahan dalam tata bahasa seperti lupa kosakata bahasa inggris yang mereka ganti dengan bahasa inggris versi mereka ataupun salah dalam spelling, tetapi hal ini tidak menyurutkan kepercayaan diri mereka untuk tetap bicara, bicara dan bicara.

Hasil yang diperoleh dari PkM ini tidak terlepas dari pendekatan yang dilakukan yaitu Simulasi, Praktek dan Pendampingan. Secara umum menunjukan bahwa pendekatan yang dilakukan dalam PkM ini memberikan pengaruh yang baik dalam peningkatan kemauan berbicara bahasa inggris santri. Pengaruh dari pendekatan yang dilakukan pada PkM Speaking Marathon ini bisa digambarkan sebagai berikut: 1). Simulasi. Video Speaking Marathon yang disusun oleh dosen dan mahasiswa UNPAM memberikan gambaran jelas bagaimana mempraktekan speaking marathon. 2). Pendampingan yang dilakukan guru bukan hanya pada saat aktivitas tetapi sebelum aktivitas Speaking Marathon. Guru pendamping melakukan brainstorming untuk membuka mindset siswa akan pentingnya berbicara dalam bahasa inggris. Dalam proses brainstorming disebutkan pula aturan jelas Speaking Marathon yang melarang siswanya melakukan kesalahan berbicara sehingga memotivasi siswa terus bicara dengan rasa nyaman dan percaya diri. Dalam proses brainstorming ini, guru juga berbagi pengalaman dengan siswa terkait tips-tips mengelola rasa gugup menjadi motivasi sehingga diharapkan siswa bisa bercermin pada pengalamannya. Dengan kata lain pengalaman guru pendamping bisa dijadikan role model bagi siswanya, sedangkan model adalah suatu hal yang ingin ditiru (Hidayanto, 2013). Sama halnya ketika kita membaca kisah inspiratif kesuksesan seseorang tentunya kita ingin mengikuti cara dan tips bagaimana orang tersebut berhasil . 3). Praktek. Anderson (2016) menemukan bahwa praktek meningkatkan awareness pembelajar akan ketidaksesuaian antara harapan dan kondisi realistis, sehingga 'praktek' membantu santri meningkatkan kondisi realistis mereka terhadap harapan mereka. Dengan kata lain, praktek meminimalisir gap/ketidaksesuai antara harapan dan realita santri. Dalam hal Speaking Marathon, fokus utama adalah bicara (speaking English). Sedangkan bicara atau speaking adalah bentuk praktek dari pengungkapan pola piker, ide dan keterampilan bahasa santri. Sehingga dalam hal ini, Speaking Marathon telah mendorong siswa untuk mengungkapkan, mensinkronkan dan meminimalisir gap antara daya fikir, ide mereka dengan keterampilan berbahasa mereka seperti reading, vocabulary dan listening secara langsung.

\section{Penutup}

\section{Simpulan}

1. Kegiatan PkM yang bertema Speaking Marathon sebagai solusi meningkatkan kemauan berbicara santri pesantren Al-Ghozali dalam berbicara bahasa Inggris 
dilaksanakan dalam bentuk Video Simulasi dan pendampingan dikarenakan adanya pandemi Covid-19.

2. PkM ini menggunakan metode Speaking Marathon yang membiasakan siswa untuk terus berbicara tanpa henti selama jangka waktu yang ditentukan dengan mengesampingkan kesalahan pada tata bahasa, kosakata dan spelling

3. PkM menggunakan pendekatan simulasi dan pendampingan dengan melibatkan theory Willlingnes to Communicate yang fokus pada peningkatan motivasi, rasa percaya diri dan meminimalisir rasa takut dan khawatir

4. PkM ini berhasil menghasilkan luaran berupa jurnal pengabdian masyarakat.

\section{Saran}

1. Apapun teknik berbicara dalam bahasa Inggris yang diberikan kepada siswa, guru pendamping harus tetap menunjukan antusiasme dalam pembelajaran, karena antusiasme guru merupakan modal dasar bagi guru untuk memotivasi siswa dalam meningkatkan kemampuan berbicara bahasa inggris.

2. Untuk mendukung metoda berbicara bahasa Inggris seperti halnya Speaking Marathon sebaiknya dilakukan berulang dalam berbagai tema sehingga terjadi pembiasan. Di samping itu, guru pendamping memberikan topik topik yang menarik yang sesuai dengan perkembangan umur siswa. sehingga siswa termotivasi untuk selalu terlibat dalam pembelajaran dengan nyaman.

3. Pada akhirnya guru perlu terus meningkatkan profesionalisme dam kompetensinya dalam bagaimana menciptakan proses belajar mengajar yang bukan hanya harus bervariasi tetapi juga harus kreatif menciptakan proses pembelajaran yang menyenangkan sehingga siswa tidak bosan.

\section{Ucapan Terima Kasih}

1. Terima Kasih Sebesar-besarnya kepada Pihak LPPM UNPAM yang telah memfasilitasi kegiatan PkM sehingga bisa terlaksana dengan baik dan lancar

2. Terima kasih kepada Pihak Pesantren Al-Ghozali yang telah memberikan kesempatan untuk mengaplikasikan Speaking Marathon di pondok pesantren AlGhozali

\section{DAFTAR PUSTAKA}

Anderson, J. (2016). Why practice makes perfect sense: the past, present and potential future of the PPP paradigm in language teacher education. Practice, 19, 14-22.

Anggraeni, A., \& Rachmijati, C. (2017). Aplikasi pemahaman lintas budaya dalam pembelajaran speaking untuk mengatasi kecemasan berbicara pada mahasiswa semester 2 program study bahasa Inggris STKIP Siliwangi. Jurnal Ilmiah P2M STKIP Siliwangi, 4(2), 32-39.

Brown, H. (2001). Teaching by principles: An interactive approach to language pedagogy. Longman. 
Lida Holida Mahmud, Yamin, Mursyid Anwar \& Tryana

Celce \& Murce.(Ed). (2001). Teaching english as a second or foreign language. Henley\&Heinley.

Fulmer, B. N. (2010). An investigation of willingness to communicate, communication apprehension, and self-esteem in the workplace [Unpublished thesis]. University of Tennessee.

Hidayanto. (2013). Berpikir sistem, pola berpikir untuk pemahaman masalah yang lebih baik. Leutika Prio.

Khayyirah, B. (2013). Cara pintar berbicara cerdas di depan public. Diva Press.

MacIntyre, P. D., Clément, R., Dörnyei, Z., \& Noels, K. A. (1998). Conceptualizing willingness to communicate in a L2: A situational model of L2 confidence and affiliation. The Modern Language Journal, 82(4), 545-562.

Xie, Q. M. (2011). Willingness to communicate in English among secondary school students in the rural Chinese English as a foreign language (EFL) classroom [Unpublished thesis]. Auckland University of Technology. 